\section{WOMEN'S FATE AND FAITH AS TOLD IN AMY TAN'S THE JOY LUCK CLUB}

\section{Napat Tangapiwut ${ }^{1}$}

\begin{abstract}
Culturally, women, regarded as weak, submissive and emotional social entities, are destined to be silent and inferior to men in a patriarchal society; however, this long-established position for women has caused them shame which today has turned into angst, leading them to question traditions, breaking their silence, revealing their painful yet rebellious experience by means of storytelling, as well as encouraging and hoping for their descendants through self-assertion have a better future. The female Chinese American writer, Amy Tan, with her first renowned novel telling stories of Chinese diaspora in America, The Joy Luck Club (1989), expresses the writer's faith in women's better opportunities when they are able to articulate their needs and strengthen their self-determination. This paper discusses women's fate and faith as shown through different Chineseimmigrant mothers' life stories that are revealed to their American-born daughters who face a dilemma in life. The mothers' stories aim to empower their daughters and help them find solutions. Storytelling is an important means for the Chineseimmigrant mothers to communicate with their daughters, inuring the children to back to their ethnic roots, to better knowing about themselves thereby ensuring them their right to choose for
\end{abstract}

\footnotetext{
${ }^{1}$ M.A. Student, Faculty of Foreign Language, Zhejiang Normal University, China
}

their own happiness. To sum up, even if women are fated to be born at a disadvantage, they can have faith in themselves if they struggle hard enough for the chance and change. More or less, women's fate and faith are likely to go hand in hand like two sides of the same coin, as do sorrow and joy in a person's life.

\section{Introduction}

In a patriarchal society women are taught to be silent culturally and historically. As females, they are stereotyped as weak, emotional, indecisive and submissive social entities who require protection and guidance from men. Therefore, women's social status is basically inferior in comparison with men's. Even worse, by being oppressed by a male-dominated society, women allow their lives to be subordinated to men's will and rarely think of their own worth. In this regard, the social values and the system structured by patriarchy make women susceptible to being either losers or victims. However, following social developments, especially in the West, civil rights, feminist movements and multiculturalism are now widely advocated and they aim for equality of opportunity and living for everyone.

In addition, the legitimacy and practicality of gender stereotyping determined by old traditions are constantly questioned in women's writing that is a great channel for generating women's voices. Since an idea without action yields no change, women have to do something in reaction to discrimination on the grounds of gender stereotyping. In other words, to force a turn in women's history, they have to play an active role in getting rid of the stereotype of women's passivity. In this 
way, in order to change society's attitude to women, they must first change their attitude towards themselves, believing that they can make a better tomorrow.

Published in 1989, The Joy Luck Club, a popular piece of English fiction by the Chinese American female writer, Amy Tan, is one such woman's voice that reveals the shame and hardships women suffer in a patriarchal society and expresses women's angst and their faith in the opportunity to articulate their needs and to strengthen their self-determination. In particular, Amy Tan suggests that women's angst as a result of being the oppressed, has caused them to break their silence and reveal their painful, yet assertive past as an invaluable life-lesson for their descendants who unavoidably fall into similar situations even though in a different context-generation, time, culture and place. In this respect, women hope for "herstory" to make a change in the society where women find their own voice and happiness.

This particular novel, women's fate and faith are shown through the life stories of four Chinese-immigrant mothers who are later revealed to their American-born daughters who have not escaped a dilemma in life. The mothers who have experienced suffering in patriarchal China talk to their daughters about their tragic life and how they escaped, letting their children become aware of the roots of their suffering and empowering their daughters to opt for the satisfactory solutions that are possible in the context of America. It can be said that the talk-story or storytelling is an important means for the Chineseimmigrant mothers to communicate with their daughters, taking the children back to the ethnic roots that have nurtured women's weakness but ensuring them their right and power to choose their own happiness. The novel stipulates that even if women are fated to be born disadvantaged, they should not lose faith in themselves by struggling hard for the chance to change. More or less, women's fate and faith are likely to go hand in hand as if they are two sides of the same coin, as do sorrow and joy in a person's life.

To point out how women suffer from their silence in the context of patriarchy and sexism and how they can break their silence to find happiness as experienced by Chinese and Chinese American women, this paper focuses mainly on Amy Tan's idealized women; in others words, the main female characters in The Joy Luck $C l u b$, their fate and faith under the limitation of patriarchal societies structured in both China and America. The paper firstly discusses how Amy Tan's life apparently influences her work, and her concept of women's fate and faith, and of idealized women. Later, it describes the sexism in a patriarchal society which determines women's fate or predestination as silent, inferior social beings. Then, the social developments in America, such as civil rights and feminist movements, are discussed in order to understand the circumstances where women's faith in their betterment is enhanced. Finally, the women's fate and faith as recounted in Amy Tan's The Joy Luck Club are specifically investigated. The paper aims to understand the cultural and social background of Chinese and Chinese American women and to study certain issues of concern that the writer, Amy Tan, is examining via the study of the women's fate and faith as told in this of her bestselling novel. 


\section{Amy Tan's life and work in relation to fate and faith}

To understand Amy Tan's writings, the writer's personal background is of importance because her works are written from real life and experience. E.D. Huntley has said, "Both Daisy and John Tan [Amy Tan's parents] had unusual backgrounds that would, in due course, provide their daughter [Amy Tan] with a great deal of narrative material for her novels" (Huntley 1998: 1). That is to say, being born as a member of the second generation of Chinese diaspora in America, Amy Tan experienced cultural conflicts between her parents' Chinese culture and the American culture she was born into; sexism in patriarchal societies; English spoken differently by her mother and mainstream America; racial discrimination in American society; assimilation into mainstream culture while understanding Chinese heritage; as well as seeking achievement and acceptability in America. These were the bountiful sources of inspiration for Amy Tan's works.

Amy Tan's life is the reconciliation of contradictory parallels; to name but a few, the East and the West, Chinese heritage and American acculturation, tradition and the contemporary, past and present and questions of fate and faith. All of these elements are synchronized into Amy Tan's being and thinking, indeed, her life. In particular, these reconciliations have been of benefit to her, as a writer, with abundant material for her plots and narratives, writing technique, as well as the influence of mother-daughter bond on her writings owing to the close relationship with her mother.

In her book, The Opposite of Fate (2003), Amy Tan points out that her life has been led by fate and faith. While her father placed his strong faith in God as a good Christian, her mother always blamed fate as the reason for their misfortunes. Believing in fatalism, her mother often warned Amy that bad things would happen if a young girl like her were disobedient. For example, if you were to eat fruit without washing it first, you would get disease inside you, and if you were to let a boy kiss you, you would have to kill your baby, and if you disobeyed, your mother would die soon. The last of these warnings threatened Amy Tan most.

Being desperate to understand the origin of her mother's pessimism in order to resolve their conflicts, Amy Tan was keen on her mother's past memories, especially those that happened in China. She found out women's suffering in patriarchal China from her mother and her grandmother (Jing-mei)'s stories. The young widow, Jing-mei, was forced to become a rich man's concubine, who raped her to prevent a refusal of his proposition, and her unacceptable remarriage caused her to be excluded from her own family. Jingmei's new-born son was taken away by one of the rich man's principal wives, who claimed the baby as her own. Finally, a miserable Jing-mei committed suicide. Unfortunately, Daisy grew up without parents and was later caught up in an unhappy, arranged marriage with an abusive husband. She later fell in love with a Chinese man working for the U.S. Information Service, John Tan, and they committed adultery which led to Daisy's imprisonment and John's immigration to America. In 1949, after her release from jail, she left everything in China, including her three daughters, got divorced and immigrated to America. Daisy met and married John Tan. Not until 1987, was she able to be reunited with her three 
daughters in China. With John Tan, Daisy gave birth to two boys and a girl (Amy Tan). It would have been a happy-ending if their first child and John had not suffered from brain cancer and died at only six months apart from each other when Amy was fifteen years old. In fact, Amy Tan, at the age of six, knew about death when her mother brought Amy to her playmate, Rachel's, funeral. At the time, her mother told Amy, "This what happen you don't listen to mother" (Tan 2003: 17).

Human-beings are certainly doomed to die but what is important to know is how to live your life while you are still breathing. As a saying goes, "Where there is life, there is always hope". This explains why the Tan family chose to settle in America, a new land with a promising future and better opportunities. Amy Tan insists she is fully an American even with her Chinese ancestry. She thinks and behaves as an ordinary American, she got married to an American (Lou DeMattei), and she believes in the freedom to express ideas and in the right to acquire equal opportunity to success and happiness. Also, she believes that hope is always deep inside everybody's mind, including her mother. As she has written, "My mother, who taught me the many permutations of fate, was hope's most stubborn defender. If fate was the minute hand on a clock, mindlessly moving forward, she could find a way to force it go back. She did it often" (Tan 2003: 3).

Amy Tan's life between fate and faith is reflected throughout her writings. For fate, the fateful story of Amy's grandmother is told through the character An-mei Hsu's mother in The Joy Luck Club. Daisy's separation from her three daughters is also told through the life of the character
Suyuan, who lost and found her twin daughters in China. Amy's second novel, The Kitchen God's Wife (1991) is mostly based on her mother's life through the character, Winnie, who undergoes hardships and an unhappy first marriage in China in wartime.

Amy Tan finishes her novels with the definition of faith; that is, "the confident assurance that something we want is going to happen. It is the certainty that what we hope for is waiting for us even though we still cannot see it ahead of us" (Tan 2003: 23). Amy's protagonists are those who successfully overcome their fate. Not forgetting their cultural roots, whether these are the origin of their strength or weakness, they are assimilated into American mainstream. In her novels, Amy Tan creates idealized women, women with a strong will to succeed. They no longer accept their fate under the traditional stereotypes of gender roles; on the contrary, they accept their fate as defined by themselves and based on a strong faith in their potential to articulate their need for self-esteem. To these women, females should take pride in their own selves, i.e. being Chinese females, since this is an unchanging reality. What they can change is their attitude. As she has written, "If you can't change your fate, change your attitude" (Tan 1991: 284). Clearly, Amy Tan's writings represent women's voices and correct women's images. Her female protagonists' stories have been brought to public attention since the success of her first novel The Joy Luck Club that was listed on the New York Times Best-seller chart for several months and was translated into many different languages, making Amy Tan celebrated worldwide. She ends her book, The Opposite of Fate, with the following assertion, "I am no longer governed by fate and fear. I have 
hope and with that, a determination to change what is not right. As a storyteller, I know that if I don't like the ending, I can write a better one" (Tan 2003: 398).

An undeniable feature that has benefited from Amy Tan being a Chinese American storyteller is the creation of a writing style that combines the Western technique with the Chinese method of orally communicating or talk story. Chinese folklore, myth, legend and personal life stories from her mother's past memories and from her findings are retold through her modern creative writing style that was gradually acquired in the West. Thus, readers of her novels can learn something about the China of the past and traditional Chinese culture affected over time by living in contemporary America with different a culture and ideology. The past with its ambiguous truth extending to fantasy and imagination are synthesized with the reality of present and it becomes the fascination of Amy Tan's works. Huntley gives more insights into her storytelling technique in particular in The Joy Luck Club novel that, "the mothers in The Joy Luck Club...draw on traditional oral forms to shape their stories and to disguise the urgency and seriousness with which they are attempting to transmit to their daughters the remnants of a culture that is fading even from their own lives" (Huntley 1998: 32-33). Through storytelling, the mothers are able to bring their daughters back to their cultural roots, perceiving the origin of their strong and weak points.

Amy Tan admits that writing is a kind of mental therapy and it comes purely from her emotion. Since Amy Tan's fate and faith have been mostly influenced by her mother, she solves the conflicts in her mind by writing about her mother and their relationship. Her writings illustrate the bond between Chinese-immigrant mothers and their American-born daughters as demonstrated in the novel, The Joy Luck Club, that narrates the lives of four Chinese-immigrant mothers (namely, Suyuan Woo, An-mei Hsu, Lindo Jong and Ying-ying St. Clair) and their four American-born daughters (namely, Jing-mei Woo, Rose Hsu Jordan, Waverly Jong, and Lena St. Clair).

Chinese-immigrant parents want the best for their children. They value education highly as it can provide wider, better opportunities for their children. Amy Tan's mother wanted her to be a doctor as a profession and a pianist in her leisure time even though, eventually, she became a writer, a best-selling writer. Amy Tan reflects mothers' expectations of their children's achievements in her writings. The mothers in The Joy Luck Club encourage their children to make the most of having a Chinese character in American circumstances in order to lead a happy life. As Lindo Jong expresses her wish for her daughter Waverly in the chapter Double Face, "I wanted my children to have the best combination: American circumstances and Chinese character" (Tan 1989: 289). In America, people have freedom of choice based on their interest and ability. With the Chinese character, one can take advantage of hidden opportunities when not showing one's true feelings, as well as knowing one's own worth and improving it. Yin Xiao-huang says the mothers in The Joy Luck Club are well aware that their children's future is in America, knowing the urgency of integration into the mainstream and urging their daughters to succeed. Therefore, the tensions of the mother-daughter bond in this novel are the results of a "parental pressure to succeed" (Yin 2000: 232-33). The character, Jing- 
mei Woo, confesses after her failure in a piano competition that, "And after seeing my mother's disappointed face once again, something inside of me began to die. I hated the tests, the raised hopes and failed expectations" (Tan 1989: 144).

Helena Grice points out that a matrilineage is structured explicitly in The Joy Luck $C l u b$. Each section of the text itself begins with a mythical Chinese parable about the relationship between mothers and daughters. Also, all of the separate narratives of four mothers and four daughters are either narratives of separation from, or connection to, the mother (Grice 2002: 68). Jing-mei Woo rejects her mother by angrily shouting to Suyuan, "I wish I wasn't your daughter" (Tan 1989: 153) in one of their quarrels over piano lessons. Suyuan wants Jing-mei to be a talent but Jing-mei feels she is not one of them and she wants her mother to accept her for what she is. Then, after Suyuan's death, Jing-mei starts to play the piano, an act that would have pleased her mother. Also, she replaces her mother at the mah-jong table, and finally, returns to China to fulfil her mother's wish to be reunited with her long lost daughters. Grice says, "Jing-Mei's visit to China and her meeting with her Chinese sisters also symbolizes the acceptance of culture-asmotherhood too" (Grice 2002: 70). In addition, Waverly rejects her mother, Lindo Jong, when her own mother asks, "embarrass you be my daughter?" (Tan 1989: 101) in response to Waverly's objection to her mother's spread it around that she is her daughter. Also, at the beauty parlor where Waverly takes her mother to have a new hair-cut for her coming second marriage, Lindo ponders, "I am ashamed she is ashamed", and "Because she is my daughter and I am proud of her, and I am her mother but she is not proud of me" (Tan 1989: 291).
However, when Waverly visits her mother and tells of their shared family history it signals the daughter's affirmation and acceptance of the matrilineage. Likewise, the characters Rose Hsu Jordan and Lena St. Clair also show a reconciliation between mothers and daughters when they take advice from their mothers to solve their marrital problems. Thus, the motherdaughter relationships which appear to be in opposition at the beginning become united at the end of the story after the daughters learn their mothers' talk stories and follow their mothers' wisdom and see themselves in their mothers and realize their mothers' ceaseless love and care for them. The conflicts in their relationships are resolved through the compromise between the daughters' American being and the mothers' Chinese heritage.

\section{Women's fate under sexism}

"Sexism" is defined by Amy Lind as "discrimination on the basic of sex and/or gender" which occurs at several levels from the individual to institutions and involves practices that promote genderbased prejudice and stereotyping. Commonly it refers to inequalities that exist among men and women, especially where women are treated as unequal or inferior to men (Ritzer and Ryan 2011: 535). Sexual discrimination is a problem found in patriarchal society.

In patriarchy, a social organization in which power is secured in the hands of adult men who enjoy economic and social privilege (Ritzer and Ryan 2011: 441), sexism is a big obstacle to women's equality of opportunity for success because it labels women with sexual stereotyping, ranging from the "angel in the house", who is passive, weak, modest and timid to a "mad woman in the attic", 
who is manipulative, irrational and selfish. While the former is a good girl (easy to control), the latter is deemed to be a bad girl (difficult to control) in the eyes of patriarchy. In addition, Chinese American women "have been cast into a similarly bifurcated role, the 'China Doll' or the 'Dragon Lady" by Euro-American stereotypes (Guan 2007: 38).

In Chinese tradition influenced by Confucian ethics, sexual discrimination was intensely established. Chinese women's lives were traditionally controlled by "imperial decrees, such as the Three Obedience, Four Virtues and Seven Grounds" (ibid: 40). The "Three Obedience" commanded women to obey their fathers at home, their husbands after marriage, and their sons when widowed. The "Four Virtues" dictated women's good behavior i.e. modesty, polite words without gossip, a graceful manner and no extravagance and the perfecting of household work rather than outdoor activities. The "Seven Grounds" allowed husbands to divorce wives who showed disrespect to the husband's parents, produced no sons, committed adultery, were talkative, involved in theft, jealous or seriously ill. For a long time, these ethical rules for women constituted their way of life, both in and out of the home. Also, since the Chinese see sons as preserving the family lineage while daughters benefit their husbands' family, Chinese parents normally treated sons better than daughters who were often regarded as 'the others'.

Hence, Confucian values designated idealized women to be those without talent and ambition and their role was limited to the domestic sphere. Women were not supposed to have an education or speak out their needs since this was a sign of selfishness and unacceptable behavior. As a result, women tended to be silent and obedient in order to meet the social expectations as good daughters, good wives or good mothers. Inevitably, Chinese women were traditionally discriminated against and rendered invisible and powerless in ancient China.

Chinese American female writers, like Amy Tan, feel the legacy of traditional repression on women; for example, Amy was taught to be totally obedient to her parents. Also, from her family history, she learnt sexism is the cause of women's silence and suffering, as well as of her mother's fatalism. Therefore, she actively voiced her opposition against it in her writings; for example, The Joy Luck Club.

Apart from Chinese traditions that cause silence in the Chinese mothers of The Joy Luck Club, Shi Ping-ping points out two more major causes. Firstly, women find their memories of life in China unspeakable because they are full of tragedy and terror. Their lives under patriarchy are too shameful to talk about. To reveal their past is liable to recall the pain and guilt in their memories and so they want to keep them secret. Another important reason concerns language barriers since the Chinese-immigrant mothers' American English is not of the standard and at the same time, their American-born daughters have an imperfect understanding of Chinese, so communication easily turns into misunderstanding (Shi 2004: 118-162). These two causes are actually the byproducts of sexism. Chinese-immigrant mothers are discriminated against both in China and in America. With no education or English proficiency, they find it hard to successfully assimilate into the new culture. 
In short, being silent from cultural oppression in patriarchy, women unwittingly play a passive role. Even worse, many have long believed that tragedy is their fate, the predestination that they can neither avoid nor change. It can be said that women's willingness to be silent, to some extent, betrays them, bringing about deterioration in their dignity. Clearly, the system of patriarchy has placed women in a vulnerable position. They are made into an object that is manipulated by the male subject, 'the other' losing importance, the victim of abusive men and a social being without a voice. Sexism prevents women from the opportunity to success. Also, it even makes women look down on themselves, have no spirit and indifferent to the doomladen destination.

\section{Women's faith in themselves}

Women have long suffered from sexual discrimination under patriarchy. However, the evolvement of human society is dynamic. Women's cultural and historical oppression is being challenged at present. Not every woman is willing to hold her tongue and swallow her own tears. They have decided to break their silence at the right time and in the right place. They are going to find a fair balance in their relationship with men and take pride in themselves. Today, women have a better opportunity to get an education and profession. They are forming a new social image which is intellectual, respectable and powerful. The rapid growth of the economy, politics and society has required womanpower to fill up the expanding positions for which men alone are not sufficient to move the development. More and more opportunities are open to women, allowing them to envision the prospect of an equal social status with men. Of course, to actualize this expectation, women need to speak out their needs and have others know of their presence.

By breaking their silence, women hope for betterment, as do Chinese women. As suggested by Guan He-feng, there are two factors encouraging Chinese women to break their silence: internal and external ones. Internally, they are anxious and worried about sexual discrimination and realize that the problems can only be eradicated through knowledge and understanding. The external factor results from changing social conditions in the contemporary world; that is, the civil rights and feminist movements and multiculturalism, which are flourishing, particularly in America (Guan 2007: 47$50)$.

The new social movements advocate true equality in education, professions and life. The civil rights movement illustrates "the importance of faith as an impetus for social justice movements" (Ritzer and Ryan 2011: 62). "Feminism" can be both a social movement, challenging the historical subordination of women and advocating political, social and economic equality between the sexes; and a perspective on society, examining the role that sex and gender play in structuring society, as well as the reciprocal role that society plays in structuring sex and gender (Calhoun 2002: 162). Wong suggests that the key to Amy Tan's success lies partly in "a white feminist ideological need for matrilineal literature" (qtd. in Grice 2002: 66). "Multiculturalism" descriptively refers to "the coexistence of people with many cultural identities in a common state society, or community", and prescriptively concerns "the belief that racial, ethnic and other groups should maintain their distinctive cultures within society" 
(Calhoun 2002: 323). Consequently, stories of ethnicity are welcomed by mainstream culture. Yin Xiao-huang writes, "[W]ith social progress and a growing interest in multiculturalism, Chinese and Asian American authors have won more recognition in the mainstream market" (Yin 2000: 170). For instance, Amy Tan's The Joy Luck Club which was enthusiastically received by critics and the general reading public demonstrates the Americans' interest in Chinese American society.

Dissatisfied with the traditional determination of their gender roles, Chinese women are desperate for the change. Firstly, they changed their circumstance by moving to America where they hoped for better opportunities. Secondly, they have tried to survive in the new country, working hard to earn a living and encouraging their children to have good education and achievements. America was founded on the rule of freedom and democracy, far away from the traditional values of Confucianism. As Huang Gui-you notes, "the US-a country that may well be the least influenced by Confucianism due to its historicogeographical distance from China and, more importantly, to a democratic system that has overall effectively resisted any despotic system characterized by Confucian advocacy of patriarchal rule" (Huang 2005: 142-43). Iris Chang states the change in Chinese women's lives once they are in America saying that, "the typical Chinese wife had more power in the United States than she could have achieved in her home village." For one thing, as a nuclear family, they escape from the tyranny of mothers-in-law, freeing themselves from a hierarchical scheme of abuse. Also, their children enjoy more rights and privileges in America. (Chang 2003: 91-92) Chang also asserts that the future of Chinese Americans rests upon "their ability to reclaim their voices-the ability to speak out, make their presence felt, and break out of the model-minority mold that has permitted others to define and dictate the form and extent of their success" (ibid: 399). Courage and faith can make Chinese Americans speak more and more louderly to claim their existence and right to live happily in America. As a Chinese American female writer, Amy Tan has raised her voice, securing her presence through her works and she has achieved substantial success in her home land, America.

To sum up, encouraged by contemporary world phenomena, Chinese American women are aware of the necessity to proclaim their rights, to break silence and to speak for their own self-esteem. Since they have been long under control of stereotyping and internalization, it is time for them to introduce new women's images as Amy Tan has tried to do. Guan He-feng states that women who lived tragic lives in China have become "selfdirected women in the United States, where they have learned to rely on and trust only themselves" (Guan 2007: 73). Therefore, in spite of cultural pressures, women have learnt to change their attitude, to rebel against sexual discrimination, to express their new image and to direct their own destiny.

\section{Women's fate and faith as told by Amy Tan's The Joy Luck Club}

The Joy Luck Club, the novel by Amy Tan, is a gathering of Chinese American women, who are close friends and have a common experience in the old and new countries, i.e. China and America. The Club is initiated by Suyuan Woo, Jing- 
mei's mother and aims to bring good luck and happiness. Suyuan's talking about her inspiration for setting up the Club is recalled in Jing-mei's memory, "We all had our miseries. But to despair was to wish back for something already lost. Or to prolong what was already unbearable...What was worse, we asked among ourselves, to sit and wait for our own death with proper somber faces? Or to choose our own happiness?" (Tan 1989: 11-12) Suyuan's words signal the main idea of the novel, not fearing fate but looking positively ahead since happiness occurs by choice. The Club shows that Chinese American women do not give up their Chinese heritage; instead, it is an attempt to remember their historical roots. People attend the Club dressed in traditional Chinese suits, cook Chinese dishes, enjoy a Chinese game (mahjong), talk in Chinese and, in particular, share their memories from the motherland, as well as nurturing their hopes and dreams in this new country. Also, the Club symbolizes the attempt to empower Chinese American women through their storytelling. It is a good time when women are gathered to break their silence and find their own happiness.

As discussed earlier (see 3), Chinese women have long endured suffering in China's patriarchal society where Confucian values suppressed women's voices and limited women's role to housekeeping. Chinese women's crises are revealed in the stories told by the mothers in The Joy Luck Club, namely, Suyuan Woo, An-mei Hsu, Lindo Jong and Ying ying St. Clair and they clearly show the oppression they experienced under patriarchy. For example, An-mei Hsu grows up remembering her mother's tragic life. As a young widow, An-mei's mother (her name is unknown) was lured into being a concubine to a rich man, $\mathrm{Wu}$ Tsing, who raped her and devastated her life. Bearing the child of $\mathrm{Wu}$ Tsing and being disowned by her own family (her remarriage as a concubine to $\mathrm{Wu}$ Tsing was awfully unacceptable according to Confucian ethics), An-mei's mother had no other choice but to suffer life in $\mathrm{Wu}$ Tsing's family, leaving An-mei with her Popo (An-mei's grandmother). The tragic incident shows that the deep-rooted Chinese traditions that place men in a higher position than women, are highly valued and often are much more important than the family bond. Since An-mei's mother is a woman, and even worse, she cannot keep up with the family's ethical rule, thus threatening her ancestors' fame, in the eyes of her own family, she has committed a serious and unforgivable crime and deserves severe punishment. An-mei is taught to hate and forget her mother. Popo warns An-mei, "Never say her name," and "To say her name is to spit on you father's grave" (Tan 1989: 34). An-mei's mother, then, becomes a living ghost to her family. To teach An-mei to be modest and obedient, Popo tells An-mei two stories. The first is the story of a greedy girl whose belly grows fatter and fatter. After it is cut open, a large white winter melon is found. Popo says, "If you are greedy, what is inside you is what makes you always hungry" (ibid: 34). Another story is about a girl who is disobedient to her elders and one day "a little white ball fell from her ear and out poured all her brains, as clear as chicken broth" (ibid: 34). In this regard, storytelling has long played a significant role in cultivating social beliefs and norms. It is a traditional way of sustaining knowledge and ideology from generation to generation. 
Lindo Jong's life in China is defined by her engagement and arranged marriage to Tyan-yu, Huang Taitai's spoiled son. Lindo's mother starts treating Lindo as Huang Taitai's daughter, the family's 'other', as well as teaching her to behave as Huang Tai-tai's good daughter-in-law. At the time of their separation, Lindo's mother tells Lindo, "Obey your family [Huang Tai-tai's family]. Do not disgrace us" (ibid: 48). With Huangs' family, Lindo keeps in mind her mother's words and diligently works like a servant, trying her best to please Huang Tai-tai and to learn to be Tyan-yu's obedient wife. Lindo bearing Tyan-yu no son infuriates Huang Tai-tai who ignores her son's impotence and turns her frustration on Lindo harshly condemning her and ordering her to lie in bed all day. Lindo's story shows that in Chinese tradition, marriage is normally arranged by family heads without the children's opinion or consent. Also, the woman's role is restricted to the domestic sphere and her most important filial duty is to bear sons.

Ying-ying St. Clair also suffers from an arranged marriage to an abusive, womanizing husband. As a little girl, Ying-ying was taught to be silent by her Amah (Ying-ying's nursemaid), who says, "Haven't I taught you - that it is wrong to think of your own needs? A girl can never ask, only listen." (Tan 1989: 68) Also, the Chinese myth of Chang-e (the Moon Lady) is made known to Ying-ying as the tragic story of a disobedient woman who stole her husband Hou Yi's peach. After eating the peach, Chang-e flew straight away to the moon, forever separated from her husband and endured a lonely life on the moon and lost herself in an unknown place. Ying-ying ponders, "...for this was her fate: to stay lost on the moon, forever seeking her own selfish wishes. For woman is yin...the darkness within, where untempered passions lie. And man is yang, bright truth lighting our minds" (ibid: 82). Ying-ying foresees her future. She knows what is going to happen in her life; however, she does nothing to prevent any undesirable events coming to her. She allows herself to love a vulgar husband, to bear him their unwanted son, to remarry an American (Clifford St. Clair) without love, and so on. Significantly, the tragedy of her first marriage leaves Ying-ying with no spirit and enthusiasm for life. She says, "I let myself become a wounded animal. I let the hunter come to me and turn me into a tiger ghost. I willingly gave up my chi, the spirit that caused me so much pain...I became an unseen spirit" (ibid: 285). Ying-ying's passivity causes her tragic life, keeps her in silence and results in her being misunderstood by the family members of her second marriage. Clifford basically interprets Ying-ying's reaction in the way he thinks. Despite Lena's understanding of her mother's Chinese, she hardly gets the real meaning and considers her mother's sayings crazy or nonsensical. Also, Ying-ying is unhappy, aware of her pregnancy she expects some fateful thing to happen and because of this she feels unbalanced. Her fears come true when the baby boy dies immediately after birth. Ying-ying blames herself and becomes more miserable. Apparently, Ying-ying's life is full of pessimism and submission to what she deems to be her unavoidable fate, willfully letting others have control over her life.

The mothers' tragedies under the patriarchal society of China repeat themselves in their daughters' lives in the new country, America, for instance, in the stories of Rose Hsu Jordan (An-mei's daughter) and Lena St. Clair (Ying-ying's daughter). 
Rose Hsu is regarded by her American husband Ted Jordan as an always-say-yes wife because she appears passive and does not take any decisions, allowing Ted to completely direct everything in their marriage life. Rose speaks about Ted, "two halves creating the whole: yin and yang. I was victim to his hero. I was always in danger and he was always rescuing me...my weakness needed protection" (ibid: 125). In this regard, Rose willingly plays the female stereotypical female role as dictated by tradition. She lets Ted have power and control over her life as she says, "Ted simply decided. And I never thought of objecting. I preferred to ignore the world around me." (ibid: 126) However, Rose has to pay the price for her silence when Ted feels her indecision to be unbearable and asks for a divorce. Rose's silence results mainly from a family tragedy when her little brother, Bing, disappeared in the sea when she was responsible for taking care of him. Since then, Rose has tended to avoid taking any responsibility owing mainly to her fear of tragic consequences. Again, even though Rose is aware of the tragic forces, she does nothing to prevent them since as she says, "I think about Bing, how I knew he was in danger, how I let it happen. I think about my marriage, how I had seen the signs, really I had. But I just let it happen" (ibid: 140). Thus, as formerly, Rose prefers passivity to actively changing the circumstances in the way that she can control the outcome of her own fate effectively.

Lena St. Clair's marriage to Harold Livotny causes her inexplicable distress. She lets herself comply with the home rules regulated by her husbands, for example, every household expense has to be shared equally and strictly between them. Harold's domination of Lena is not limited only to home, but also extends to their workplace, Livotny \& Associates, which they co-founded. Lena's devotion to the company's success is ignored by her husband and so she has no promotion or salary-income with the explanation that it would be unfair to other staff to favor his own wife. As a result, Harold's salary is seven-times higher than Lena's while she is equally burdened with the family expenses. Still, Lena mistakes her unhappy marriage for an unavoidable punishment for what she did to a neighboring boy, Arnold, whom she thought was destined to be her husband. The young Lena was told that unfinished rice in her bowls would appear on her future husband's face, making him ugly. When she sees Arnold's rough face, she takes it for granted that Arnold is her future husband. Lena blames herself when Arnold dies because she intentionally leaves a lot of food unfinished or simply eats nothing.

Even though women's fate is under the constraints of the social conditions of patriarchy, Amy Tan makes her women unyielding in their opposition. Instead of being indifferent to their lives, Amy Tan's women are rebellious and fight against what they deem to be unfair and what needs to be fixed. They break silence, believing in their "nengkan" (ability) or the idea that, if they try hard enough, they will be able to attain achievement. They voice their own painful yet assertive experience to let society know who they are and what they need. This perception is expressed through the turning point in main characters' lives of both the Chineseimmigrant mothers and their Americanborn daughters. With the strong will to make a change, they are empowered to claim their rights and find a beneficial solution to their own destiny. The daughters learn life-lessons from their 
mothers and finally get out of trouble. The story verifies that breaking silence at the right time and place is a way of escaping from the despair and misfortune of women's lives.

An-mei's mother's suicide in revenge for $\mathrm{Wu}$ Tsing's family symbolizes the attempt to eliminate women's old image (weakness) and to construct a new one which is stronger and empowered. As Anmei narrates, "she would rather kill her own weak spirit so she could give me a stronger one" (Tan 1989: 271). Fearing curses from An-mei mother's ghost, Wu Tsing promises to raise An-mei and her younger brother as his honored children, as well as revering An-mei's mother as his first wife. On the day of her mother's funeral, An-mei has learnt to shout as she rages against $\mathrm{Wu}$ Tsing and his second wife, showing her powerful image.

It is An-mei who encourages her daughter, Rose, to speak up for herself in the event of her deteriorating marriage. An-mei ponders, “...if she [Rose] doesn't speak, she is making a choice. If she doesn't try, she can lose her chance forever." (ibid: 241) While An-mei considers her mother's fate as unavoidable in China's traditional society which keeps women in silence and suffering, she believes Rose can opt for happiness in the context of modern America. She says, "My mother...lost her face and tried to hide it. She found only greater misery and finally could not hide that...That was China. That was what people did back then. They had no choice. They could not speak up...That was their fate. But now they can do something else. Now they no longer have to swallow their own tears." (ibid: 272) Rose is finally empowered by her mother's story, and comes to terms with her husband. She neither signs the divorce paper nor allows Ted to have the house.

Lindo Jong is able to escape from her unhappy, arranged marriage owing largely to her strong will to decide her own destiny. Making use of traditional Chinese beliefs, she makes up the stories of ancestor's visiting in her dream and his curse on Huangs' family if she stays Tyanyu's wife, as well as the sniffled-out red candles that are rekindled by the housemaid. Her powerful will grants her the opportunity to start a new life in America. Seeing herself as strong and pure, Lindo talks to herself, "I would always remember my parents' wishes, but I would never forget myself"' (Tan 1989: 53).

Ying-ying St. Clair, who appears to be the weakest character, also decides to break her silence, revealing her painful story to her daughter, Lena, in the hope of bringing back her daughter's tiger spirit to fight against her husband's unjust treatment. Ying-ying says, “...now I must tell her everything about my past. It is the only way to penetrate her skin and pull her to where she can be saved." (ibid: 274) Yingying sees herself as a tiger ghost but she does not want her daughter to repeat the same mistake, being controlled by others and losing her own spirit. Ying-ying laments that "she [Lena] is the daughter of a ghost. She has no chi. This is my greatest shame. How can I leave this world without leaving her my spirit?" (ibid: 286)

Throughout the novel, the idea of having a strong faith in one's potentiality to being a change to a person's predestined fate is clearly spelt out. Believing in human fate remains unchanged; however, under such life constraints, women must look for the optimum conditions for having control over their own destiny. For example, 
Suyuan's strong will encourages her to fight hardship and locate her long-lost twin daughters in China. She also tries to make her daughter Jing-mei find and take pride in herself. Jing-mei, who basically devalues herself, finally fulfills her mother's wish by going to China to be reunited with her twin sisters. Like Suyuan, An-mei Hsu believes strongly in her will even though she deems it somehow fated. Also, An-mei encourages her daughter Rose to strengthen her own will in order to fix her marriage dilemma. Therefore, the power of "fate" and "faith" somehow appears as a co-dependent relationship rather than being separated. However, without "faith", the whole of life will totally fall into the hands of "fate" which often clouds one's destiny.

\section{Conclusion}

Women are culturally made silent by means of stereotyping and internalization. To be a decent woman in the eyes of patriarchal society, one must appear weak, timid, indecisive and passive. Women become selfeffacing by keeping silence. They desire for nothing and let others exploit their lives. When a woman gives up controlling her own life, others will take her place and make use of her life. Then, it is easy to see a woman as an object, a victim or a loser.

However, the growing trend of cultural movements, especially civil rights, feminism and multiculturalism, has opened women's eyes and opportunities. For so long, her life has been controlled by the false belief that her fate is destined by others or by traditional social expectation. This silence has come at a high price. Being aware of their discriminated social position, women are no longer willing to accept this unfair burden. Reformation of this patriarchal system is what these women are looking for. They are finding their own powerful self whose destiny is defined by themselves. Women's future is going to be a different and a prosperous one.

Between fate and faith, which one is more important in directing a person's life depends mainly on a person's own attitude. Chinese American women writers like Amy Tan, express their faith in a favorable light, seeing that, to some extent, women have control over their fate. These writers are now creating a new image of women, idealized women who are empowered to proclaim female rights and dignity in order to be visible and powerful in today's society.

\section{References}

Calhoun, Craig. 2002. Dictionary of the Social Sciences. Oxford: Oxford University Press.

Chang, Iris. 2003. The Chinese in America: A Narrative History. New York, London, Canada, and New Delhi: Penguin Books.

Grice, Helena. 2002. Negotiating Identities: An Introduction to Asian American Women's Writing. Manchester and New York: Manchester University Press.

Guan, He-feng. 2007. Seeking Identity Between Worlds: A Study of Chinese American Women's Literature. Kaifeng: Henan University Press.

Huang, Gui-you. 2005. "Long A Mystery and Forever a Memory: God vs. Goddess in the Ethnic Novel." Asian American Literary Studies. ed. by Huang Gui-you. Edinburgh: Edinburgh University Press. 
Huntley, E.D. 1998. Amy Tan: A Critical Companion. Westport and Connecticut: Greenwood Press.

Ritzer, George and J. Michael Ryan (eds.) 2011. The Concise Encyclopedia of Sociology. Singapore: Wiley-Blackwell.

Shi, Ping-ping. 2004. The Mother Daughter Relationship and the Politics of Gender and Race: A Study of Chinese American Women's Writings. Kaifeng: Henan University Press.

Tan, Amy. 1989. The Joy Luck Club. New York: Ivy Books.

---. 1991. The Kitchen God's Wife. London, New York, Toronto and Sydney: Harper Perennial.

---. 2003. The Opposite of Fate. London: Harper Perennial.

Yin, Xiao-huang. 2000. Chinese American Literature Since the 1850s. Urbana and Chicago: University of Illinois Press. 